\title{
Solid State Battery Using Copper Ion Conductive Solid Electrolyte Sheet and Copper Chevrel Phase Compound Electrode Flexible Sheets
}

\author{
Tadashi SotomUra*, Shuji IтоH*, Shigeo Kondo** and Tsutomu IwAKI*
}

Received July 30, 1990; Accepted October 3, 1990

\begin{abstract}
A solid state rechargeable battery using a copper ion conductive solid electrolyte sheet of $\mathrm{Rb}_{4} \mathrm{Cu}_{16} \mathrm{I}_{7} \mathrm{Cl}_{13}$ and copper Chevrel phase compound electrode sheet of $\mathrm{Cu}_{2} \mathrm{Mo}_{6} \mathrm{~S}_{7.8}$ was developed. Styrene-ethylene-butadiene-styrene copolymer rubber was admixed with the electrolyte and electrode powders to make the solid battery flexible and to minimize the leak current through the solid electrolyte sheet. The volume fraction of the rubber was optimized to be $65 \%$ in the electrolyte and $10 \%$ in the electrode. The cell with optimized electrolyte and electrode sheets provided a high current output of $10 \mathrm{~mA} / \mathrm{cm}^{2}$ with over $60 \%$ of utilization of the Chevrel electrode, holding $70 \%$ of its initial capacity after 78 days storage at $80^{\circ} \mathrm{C}$.
\end{abstract}

\section{INTRODUCTION}

Solid state batteries using solid electrolyte and solid electrodes have been extensively studied because of their advantages of long self life and no electrolyte leakage. Inorganic powders are mainly used as solid electrolyte and solid electrode. The powders are press-moulded into a three layered tablet. The solid pellet is rigid and brittle; so it has disadvantages of being fabricated in a limited form of tablet and not absorbing volume change accompanied by cell discharge or charge. Steele 1) pointed out that solid material with plasticity or elasticity was required to obtain good cell performance. To develop solid batteries flexible or elastic sheet form, solid polymer electrolytes were introduced by Wright 2 and extensively studied by Armand et al 3). Armand reported polyethylene oxide based solid polymer electrolyte and tried to fabricate lithium anode batteries with flexible

\footnotetext{
* Living Systems Research Center

** Central Research Laboratories

(Matsushita Electric Industrial Co., Ltd. 3-15 Yagumonakamachi, Moriguchi, OSAKA, 570 Japan) Key Words: Solid electrolyte, Rechargeable battery, Copper chevrel, Rubber.
}

film form 4). However poor ionic conductivity of the solid polymer electrolyte limited the practical use.

We have tried to blend synthetic rubber with solid electrolyte and electrode powders to obtain flexible solid electrolyte and electrode sheets with higher ionic conductivity and good elasticity: $\mathrm{Rb}_{4} \mathrm{Cu}_{16} \mathrm{I}_{7} \mathrm{Cl}_{13}$ copper ion conductive solid electrolyte powders with $3 \times 10^{-1} \mathrm{~S} / \mathrm{cm}$ conductivity were used for the electolyte sheets; $\mathrm{Cu}_{2} \mathrm{Mo}_{6} \mathrm{~S}_{7.8}$ copper Chevrel phase compound powders were used to form the electrode sheets.

This battery system was reported by Kanno et al. 5), providing a good charge-discharge cycle life and a higher current output because copper Chevrel phase compound intercalates or deintercalates reversibly copper ions with a smaller polarization as compared with metallic copper. This paper describes the effect of rubber binder on the charge-discharge performance and storage characteristics of the solid state rechargeable battery.

\section{EXPERIMENTAL}

\subsection{Preparation of solid electrolyte sheet}

Copper ion conductive solid electrolyte powders of $\mathrm{Rb}_{4} \mathrm{Cu}_{16} \mathrm{I}_{7} \mathrm{Cl}_{13}$, which were prepared 
by the method reported by Takahashi et al. 6), were mixed with a toluene solution dissolving 6 wt.\% SB rubber. The SB rubber was a mixt. of 80 pts.wt. of styrene-ethylene-butadiene-styrene copolymer (SEBS, Japan Synthetic Rubber Corp., Tokyo, Japan) and 20 pts.wt. of styrenebutadiene-styrene rubber (TR-2000, Japan Synthetic Rubber Corp.). SEBS has 0.91 specific gravity, 75 Shore-A hardness, $56 \mathrm{kgf} / \mathrm{cm}^{2}$ of $300 \%$ modulus, $316 \mathrm{kgf} / \mathrm{cm}^{2}$ tensile strength, $-65^{\circ} \mathrm{C}$ softening point, whose 20 wt.\% toluene soln. gave $1500 \mathrm{cps}$ viscosity at $25^{\circ} \mathrm{C}$. The solid electrolyte powders mixed with the toluene solution were pulverized with alumina balls for 2 $\mathrm{h}$ to prepare a solid electrolyte slurry. The slurry was applied to a 54 micron thick supporting mesh with $34 \%$ of opening area made of 35 micron dia. polyester yahn (NBC Ind. Corp., Tokyo, Japan). The resultant solid electrolyte sheet was heated at $80^{\circ} \mathrm{C}$ under vacuum overnight to remove toluene. The sheet was $120 \mu \mathrm{m}$ thick and was flexible.

\subsection{Preparation of electrode sheet}

Copper chevrel phase compound powders of $\mathrm{Cu}_{2} \mathrm{Mo}_{6} \mathrm{~S}_{7.8}$ were prepared by the method reported by Yamamoto et al. 7), where the press-moulded mixture of $\mathrm{MoS}_{2}, \mathrm{~S}$, and CuS powders was heated at $1000^{\circ} \mathrm{C}$ for $100 \mathrm{~h}$ under vacuum. Copper chevrel phase compound powders and the solid electrolyte powders were mixed in a weight ratio of $1: 1$; the mixture was ground and mixed with the toluene soln. to prepare an electrode slurry. The slurry was applied to a $75 \mu \mathrm{m}$ thick supporting mesh with $58 \%$ of opening area made of $35 \mu \mathrm{m}$ dia. polyester yahn. The resultant electrode sheet was heated at $80^{\circ} \mathrm{C}$ under vacuum overnight to remove toluene. The sheet was $150 \mu \mathrm{m}$ thick and was also flexible.

\subsection{Cell fabrication and construction}

The solid electrolyte and electrode sheets were cut to $80 \times 20 \mathrm{~mm}$ strips. The solid electrolyte strip was sandwiched between electrode strips; the assembly of the sheets were pressed at $170^{\circ} \mathrm{C}$ for $5 \mathrm{~min}$. at a pressure of 400 MPa to form a layered cell, which was then cut to
$15 \times 15 \mathrm{~mm}$ test cells. After current collectors of electrical conductive carbone-fluororesin composite sheet (Japan Gore-Tex Inc.) with copper foil leads were applied to both faces of the test cell by $150^{\circ} \mathrm{C}$ heat pressing, the whole cell was sealed with an aluminium-polypropylene laminated film. Figure 1 illustrates the construction of the test cell.

The cell system is described as: $\mathrm{Cu}_{2} \mathrm{Mo}_{6} \mathrm{~S}_{7.8}$ $\mathrm{SE} / \mathrm{Cu}_{2} \mathrm{Mo}_{6} \mathrm{~S}_{7.8}\left(\mathrm{SE}=\mathrm{Rb}_{4} \mathrm{Cu}_{16} \mathrm{I}_{7} \mathrm{Cl}_{13}\right)$. The positive and negative electrodes have the same composition with each other, so that the cell

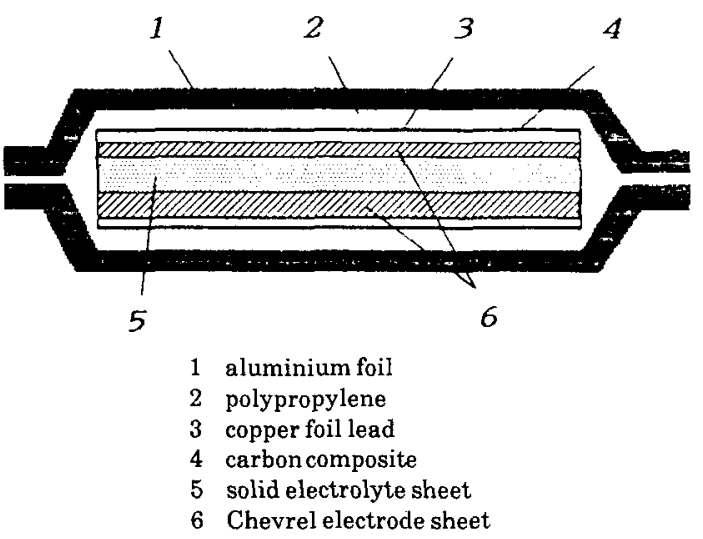

Fig. 1 Construction of the Test Cell.

Solid state rechargeable cell using copper ion conductive solid electrolyte sheet of $\mathrm{Rb}_{4} \mathrm{Cu}_{16} \mathrm{I}_{7} \mathrm{Cl}_{13}$ and copper Chevrel electrode sheet of $\mathrm{Cu}_{2} \mathrm{Mo}_{6} \mathrm{~S}_{7.8}$.

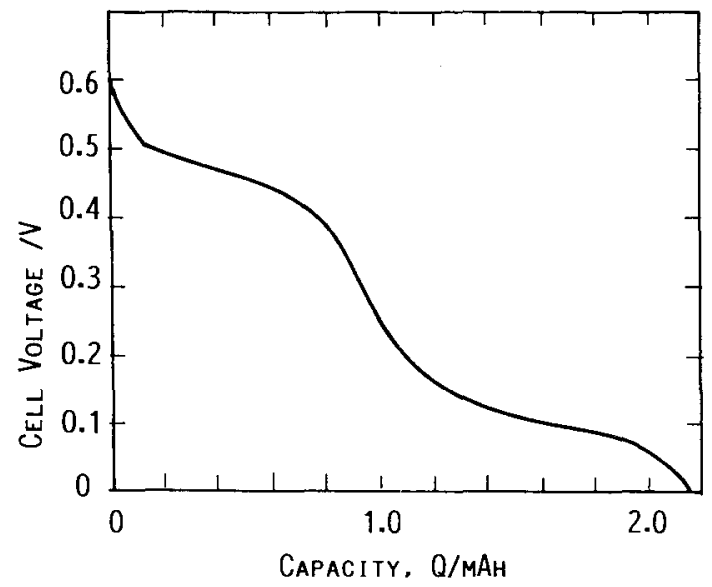

Fig. 2 Typical discharge curve of solid state rechargeable battery using copper ion conductive solid electrolyte sheet and copper Chevrel phase compound electrode sheet: the cell was charged at 0.60 volt then discharged on $0.5 \mathrm{~mA}$ at $20^{\circ} \mathrm{C}$. 


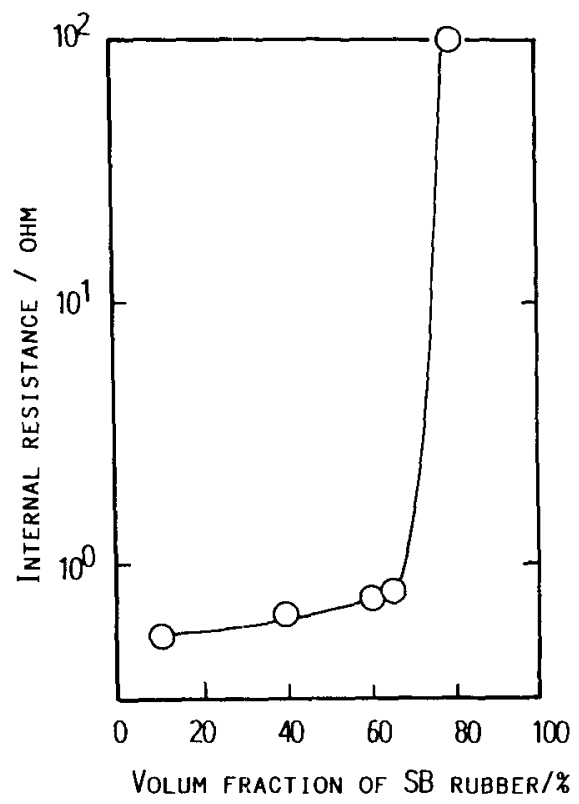

Fig. 3 Internal resistance of test cells having solid electrolyte sheets with different volume fractions of $\mathrm{SB}$ rubber at $20^{\circ} \mathrm{C}$.

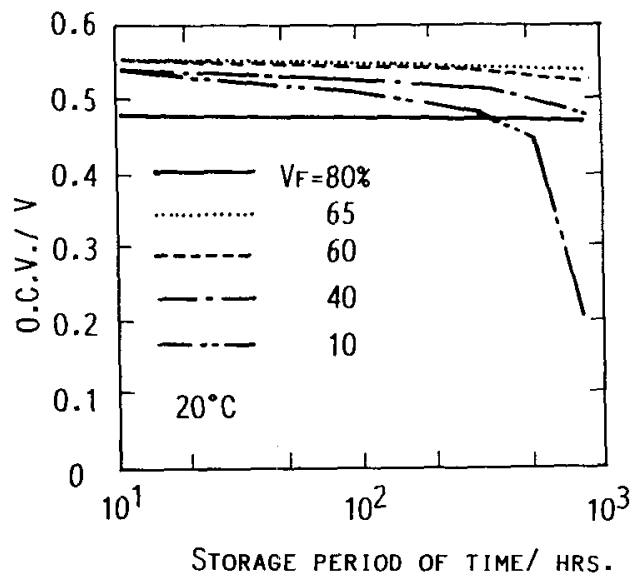

Fig. 4 Open circuit voltage (O.C.V.) of test cells having solid electrolyte sheets with $80,65,60,40$, or $10 \%$ volume fractions $\left(\mathrm{V}_{\mathrm{F}}\right)$ of $\mathrm{SB}$ rubber: the cells were charged at 0.55 volt overnight and left at $20^{\circ} \mathrm{C}$.

voltage is zero when it is fabricated. Figure 2 shows a typical discharge curve, which was given by charging the test cell at a constant voltage of 0.6 volt, then discharging at a constant current of $0.5 \mathrm{~mA}$ at $20^{\circ} \mathrm{C}$. The first step with higher voltage around 0.48 volt was considered to be corresponding to the cell reaction in which the atomic number of $x$ in $\mathrm{Cu}_{\mathrm{x}} \mathrm{Mo}_{6} \mathrm{~S}_{7.8}$ changes from 0 to 1 in the positive electrode and from 4 to 3 in the negative ${ }^{8)}$. The second step with lower voltage around 0.10 volt was considered to be corresponding to the cell reaction in which $\mathrm{x}$ changes from 1 to 2 in the positive electrode and from 3 to 2 in the negative 8 ).

\section{RESULT AND DISCUSSION}

\subsection{SB rubber content in solid electrolyte} sheet

Test cells having solid electrolyte sheets with different SB rubber content from 10 to 80 vol.\% were fabricated and their a.c. internal resistances and open circuit voltage during storage were measured.

Figure 3 shows the a.c. internal resistance measured by $4274 \mathrm{~A}$ multi - frequency LCR meter (Yokogawa Hewlett Packard Corp.) at a frequency of $10 \mathrm{kHz}$ and an amplitude of $100 \mathrm{mV}$

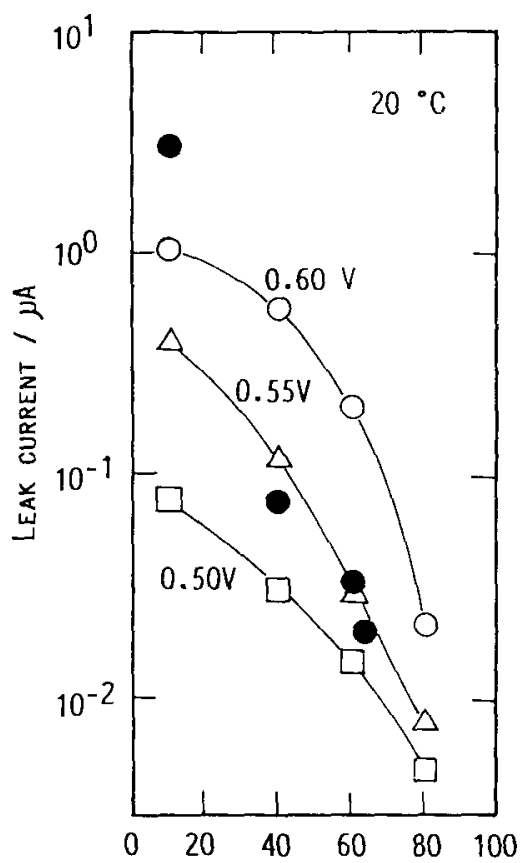

VOLUME FRACTION OF SB RUBBER/\%

Fig. 5 Leak current and average leak current passed through the solid electrolyte sheets with different volume fraction of SB rubber: leak current was measured by polarizing $\mathrm{Pt} / \mathrm{SE} / \mathrm{Cu}$ cell at a constant voltage of $0.50,0.55$ and 0.60 volt (vs $\mathrm{Cu}$ ); average leak current ( $)$ was calculated from the o.C.V. change of test cells during storage. 
at $20^{\circ} \mathrm{C}$. It increased slightly from 0.4 to about $1 \Omega$ with the SB rubber content in the range of 0 to 70 vol.\% however around 70 vol\% it provided an abrupt increase to over $100 \Omega$.

Figure 4 shows the open circuit voltage change of the test cells which were left at $20^{\circ} \mathrm{C}$ in open atmosphere after they were charged at a constant voltage of 0.55 volt overnight. The average leak current was calculated from the O.C.V. change from 0.55 to 0.50 volt on the assumption that the O.C.V. lowering was attributed to the self-discharging caused by electronic leaking through the solid electrolyte sheet. They are given in Fig. 5 as closed circles. The average leak current was decreased from $3 \mu$ A to $0.02 \mu \mathrm{A}$ by increasing the SB rubber content from 10 to 65 vol.\%.

The leak current was directly measured by polarizing the $\mathrm{Pt} / \mathrm{SE} / \mathrm{Cu}$ cell $(\mathrm{SE}=\mathrm{solid}$ electrolyte). The cell was constructed by sandwiching a solid electrolyte sheet disc between $\mathrm{Pt}$ disc anode and $\mathrm{Cu}$ disc cathode $10 \mathrm{~mm}$ dia. It was polarized at 0.50 .0 .55 or 0.60 volt, and the current passed through the cell was measured after it reached a steady value. The result is given also in Fig. 5. The leak current decreased by about 10 to 20 times as the SB rubber content increased from 10 to 70 vol.\%. The calculated average values and the measured ones gave good agreement.

Figure 6 are the SEM images of surface and cross sections of the solid electrolyte sheets with $10,40,60,65$, and 80 vol.\% SB rubber content. The electrolyte particles are totally separated from each other in the sheet with 80 vol.\% SB rubber content. In the 65 vol. $\%$ sheet, they are also separated, but with a narrower distance and less aggregated than 80 vol.\% sheet. This complex microstructure might bring the unexpected effect of decreasing leak current while maintaining low internal resistance.

The average thickness of rubber binder coated on solid particles can be related with the volume fraction of rubber binder $\left(\mathrm{V}_{\mathrm{F}}\right.$ in $\left.\%\right)$ in an ideal
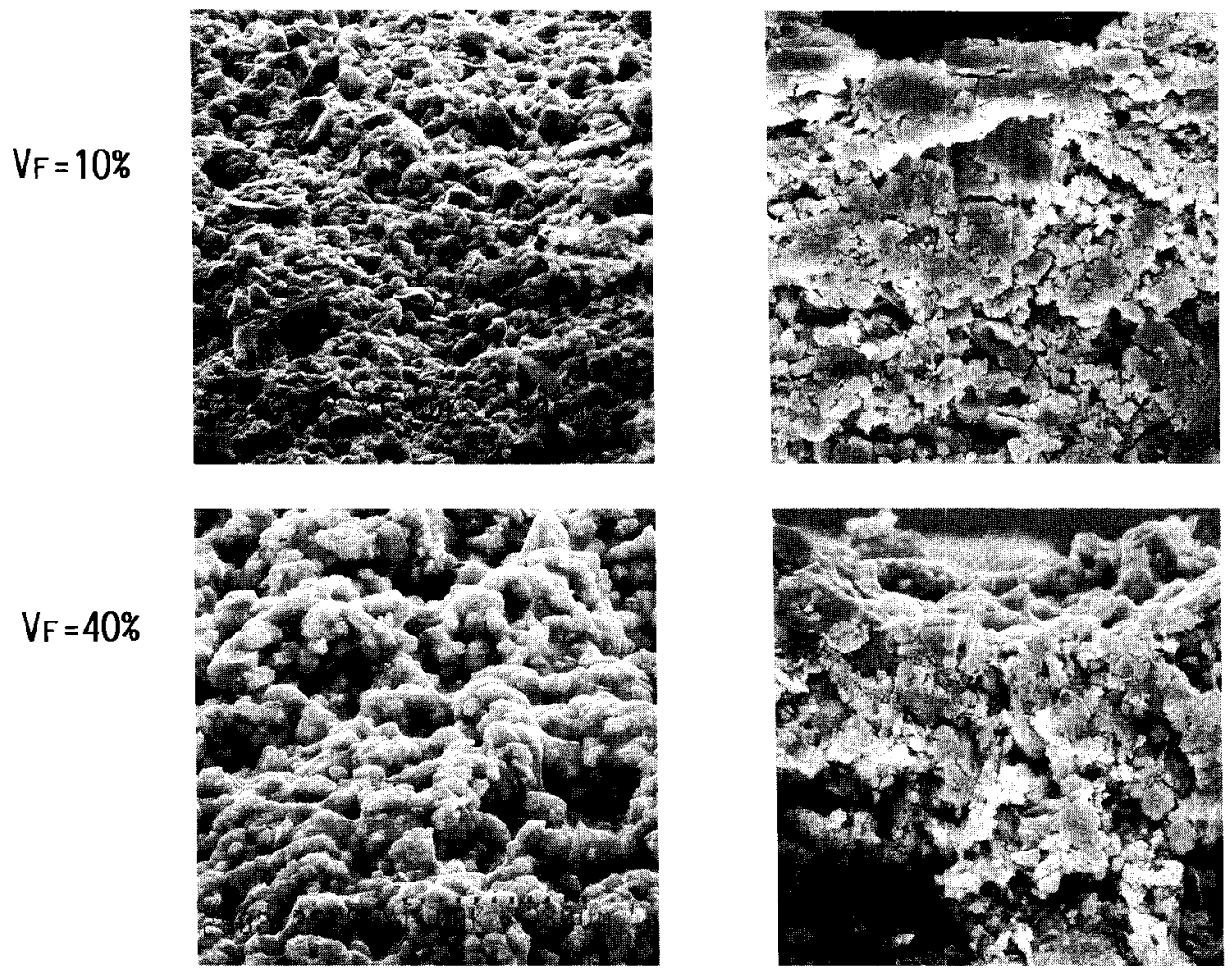

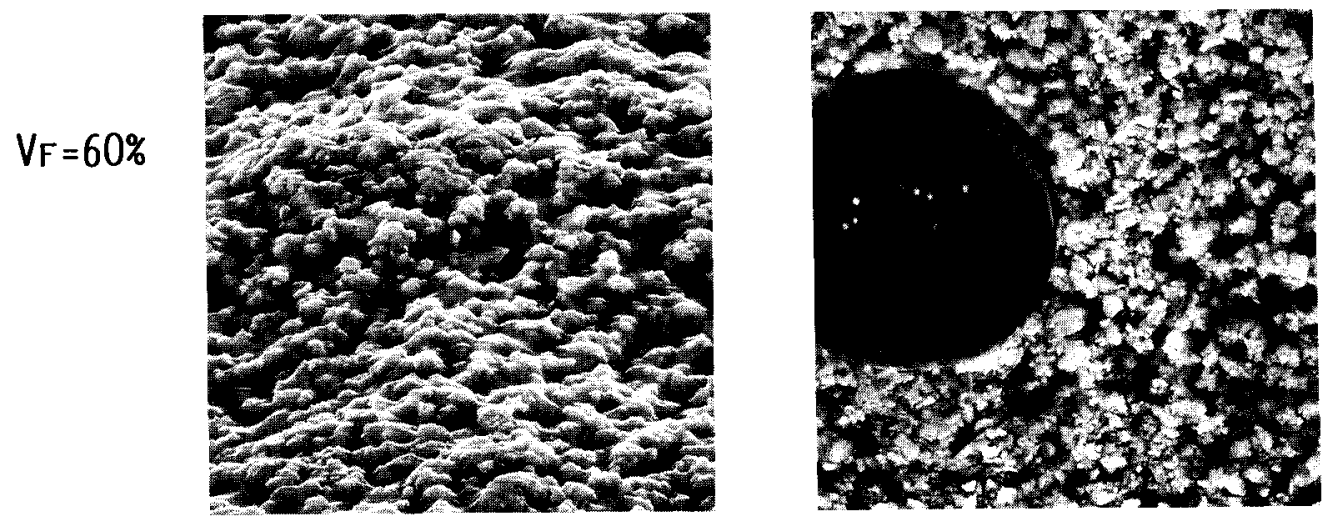

$V_{F}=65 \%$
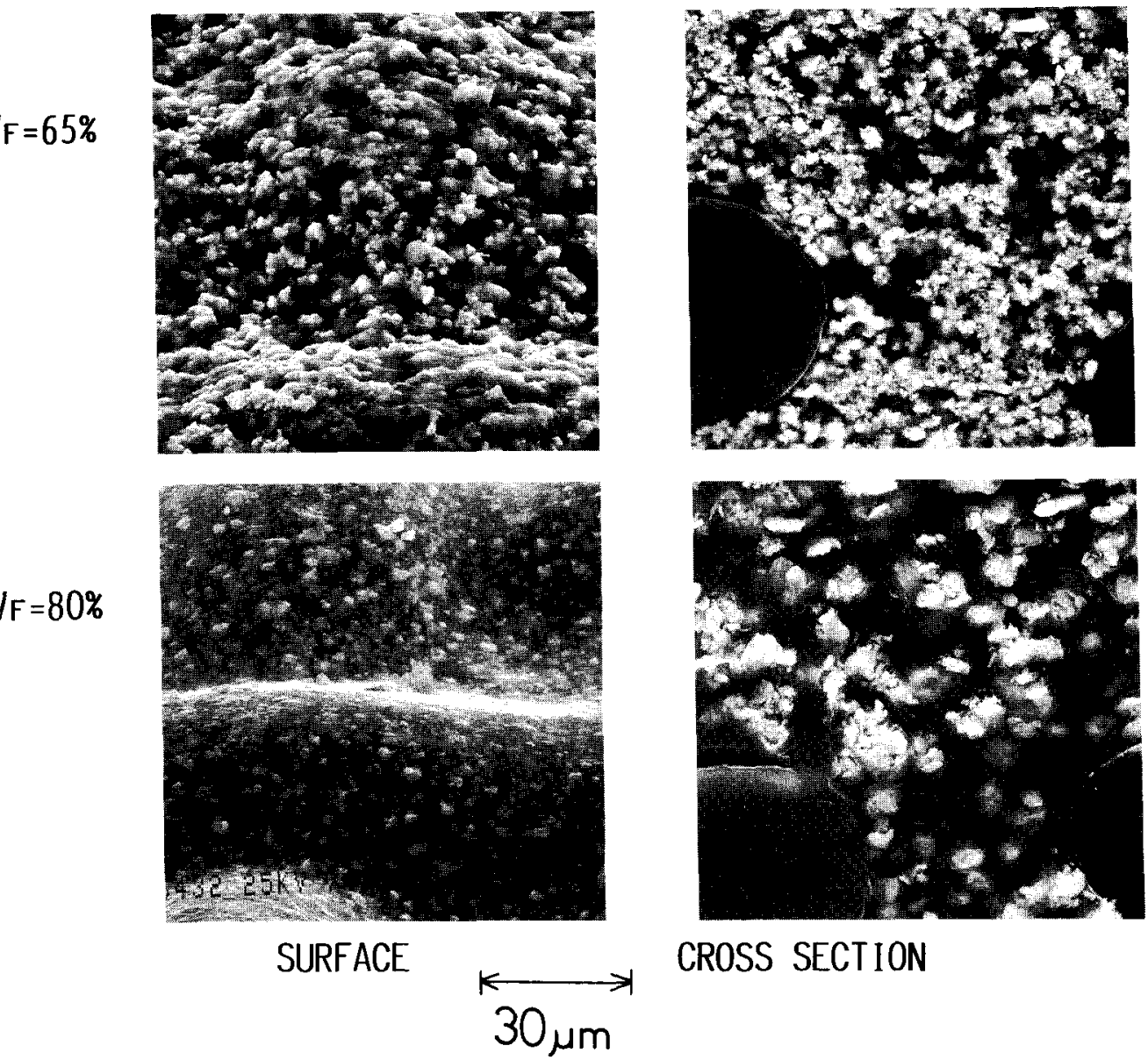

CROSS SECTION

Fig. 6 SEM images of the surface and cross section of solid electrolyte sheets with SB rubber volume fractions $\left(\mathrm{V}_{\mathrm{F}}\right)$ of $10,40,60,65$, and $80 \%$.

system where cubic solid particles with $L$ length of the side are uniformly dispersed. Figure 7 shows the relation. The average distance parting the cubic solid particles having $1 \mu \mathrm{m}$ length of the side $(\mathrm{L}=1 \mu \mathrm{m})$ are $0.03 \mathrm{~L} \times 2=600 \AA$ for $\mathrm{V}_{\mathrm{F}}=20 \%$; $0.2 \mathrm{~L} \times 2=4000 \AA$ for $\mathrm{V}_{\mathrm{F}}=55 \% ; 0.4 \mathrm{~L} \times 2=8000 \AA$ 


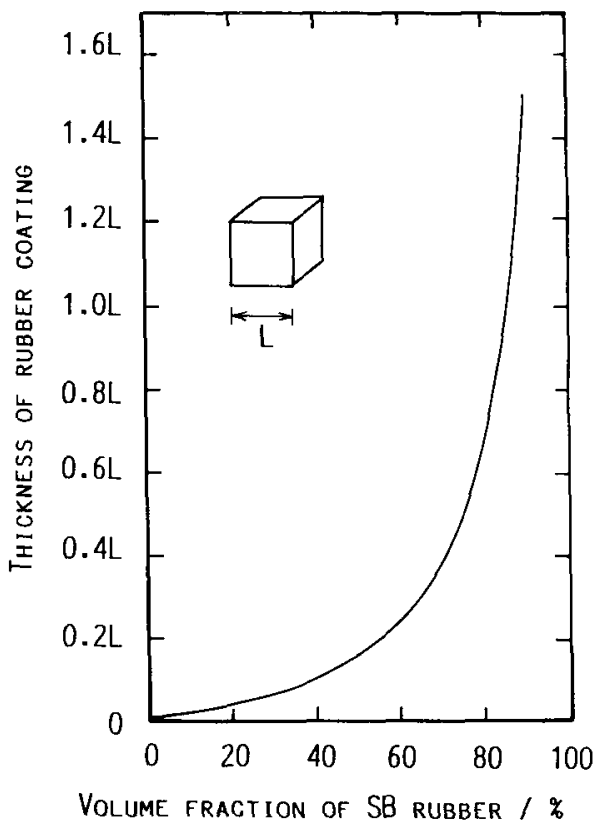

Fig. 7 Relation between thickness of rubber binder coating and volume fraction in rubber binder-cubic solid particle composite: cubic solid particles with $\mathrm{L}$ length of the side are coated with rubber binder.

for $V_{F}=70 \%$. In Fig. 8 are shown schematically the two dimensional array of the ordered or disordered cubic solid particles dispersing in the composites with 20,55 and 70 vol.\% of rubber binder. Solid particles are intimately packed and can be directly contacted with one another in the composite of $V_{F}=20 \%$, while they are totally separated from one another in the $\mathrm{V}_{\mathrm{F}}=70 \%$ composite. In the range of 20 to $70 \mathrm{vol} . \%$, the number of the solid particles directly contacting with one another becomes smaller as the rubber content increases; so ions and electrons are required to conduct through the layer of the insulating rubber binder. Assuming that copper ions could travel across the rubber binder layer with a thickness at which electron tunneling is prohibited, we can explain the results of unexpectedly larger reduction in leak current with minimum increase of internal resistance. Further studies are required to ascertain the above speculation.

In this way the SB rubber content was optimized to be $65 \mathrm{vol} . \%$ in the electrolyte sheet at

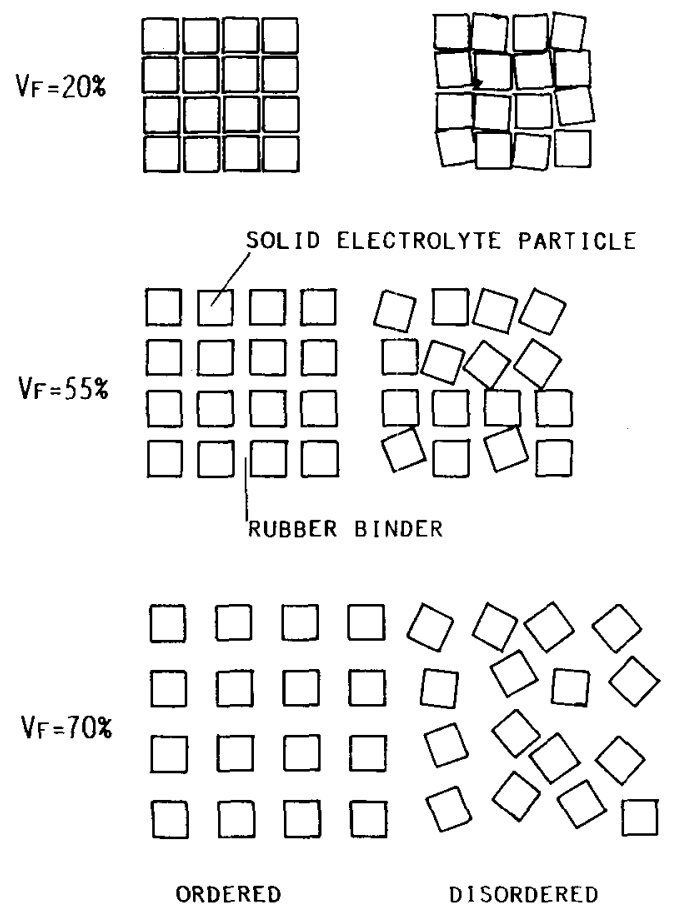

Fig. 8 Illustration of ordered and disordered arrays of cubic solid particles with $L$ length of the side in a rubber binder-cubic solid particle composite with different volume fractions of rubber binder.

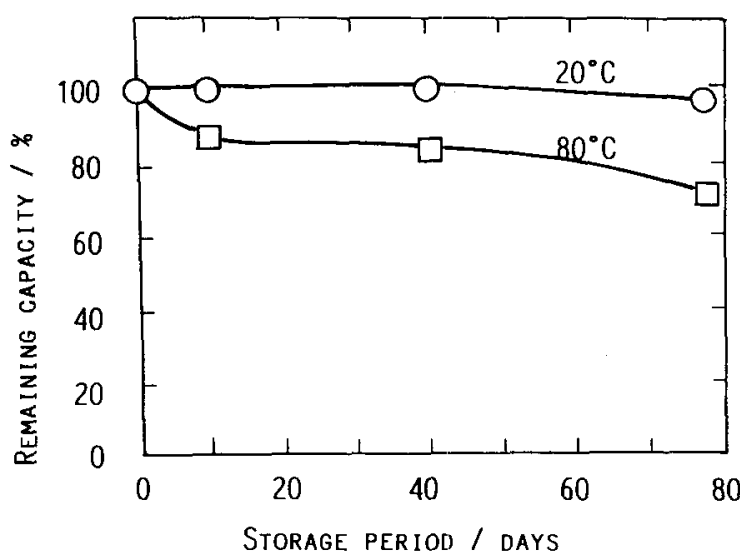

Fig. 9 Storage performance of test cells having the solid electrolyte sheet with optimized SB rubber content of 65 vol.\%: the test cells were charged at 0.60 volt at $20^{\circ} \mathrm{C}$ overnight, left at 20 or $80^{\circ} \mathrm{C}$ over 78 days, and discharged on $0.5 \mathrm{~mA}$ at $20^{\circ} \mathrm{C}$ down to 0.30 volt to obtain remaining capacity. Volume fraction of SB rubber in the electrode sheet was $10 \%$. 
which a longer self life and a lower internal resistance, i.e., a higher current output, can be expected.

Figure 9 shows the storage characteristics of the test cells with the optimized solid electrolyte sheet having 65 vol. $\%$ SB rubber. The test cells were left at 20 and $80^{\circ} \mathrm{C}$ over 78 days in open atmosphere after they were charged at 0.6 volt overnight, then they were discharged at $20^{\circ} \mathrm{C}$ on a constant current of $0.5 \mathrm{~mA}$ down to 0.3 volt. At least $70 \%$ of the initial capacity was kept even after 78 days storage at $80^{\circ} \mathrm{C}$.

After they were discharged to measure the remaining capacity they were charged again at 0.60 volt overnight and discharged. Every test cell provided almost $100 \%$ of their initial capacity; so that there might be no side reactions which bring capacity losses during storage and that the capacity losses might be attributed only to the electronic leaking across the solid electrolyte sheet.

The current output of the test cell with the solid electrolyte sheet having an optimized SB rubber content of 65 vol.\% is given in Fig. 10 with respect to the utilization of the Chevrel electrode. The utilization $\left(Q_{\text {eff }}\right)$ was calculated from the theoretical capacity $\left(Q_{\text {th }}\right)$ which corresponds to the compositional change from $\mathrm{Cu}_{0} \mathrm{Mo}_{6} \mathrm{~S}_{7.8}$ to $\mathrm{Cu}_{1} \mathrm{Mo}_{6} \mathrm{~S}_{7.8}$ and the discharge capacity $\left(\mathrm{Q}_{\mathrm{dis}}\right)$ which was measured by charging the test cell at 0.6 volt for $17 \mathrm{~h}$ overnight; then discharging it on

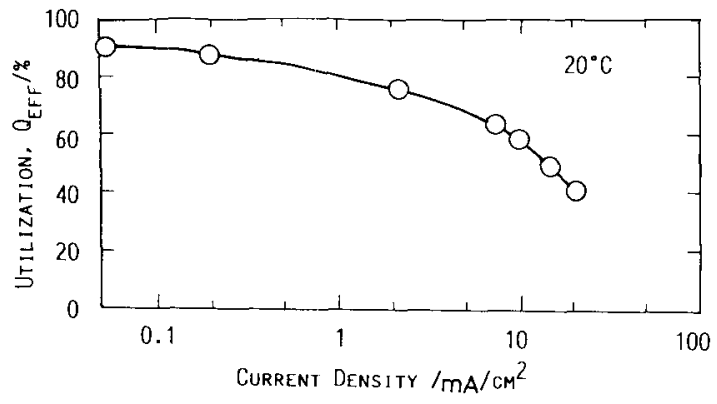

Fig. 10 Current output of test cells having the solid electrolyte sheet with optimized SB rubber content of $65 \%$ : the test cells were charged at 0.60 volt overnight, then discharged on a given current down to 0.30 volt. Volume fraction of SB rubber in the electrode sheet was $10 \%$. a constant current of $0.5 \mathrm{~mA}$ down to 0.3 volt at $20^{\circ} \mathrm{C}: Q_{\text {eff }}=100 \times Q_{\text {dis }} / Q_{\text {th }}(\%)$. The cell was capable of delivering over $10 \mathrm{~mA} / \mathrm{cm}^{2}$ current at $20^{\circ} \mathrm{C}$ with over $60 \%$ Qeff.

\subsection{SB rubber content in Chevrel electrode}

The utilization of the Chevrel electrode sheet with different SB rubber content 5 to 30 vol. \% was measured by charging the test cells at 0.60 volt for $17 \mathrm{~h}$ overnight and discharging them at a constant current of $0.5 \mathrm{~mA}$ down to 0.3 volt. The result is given in Fig. 11. The electrical resistance of the electrode sheet was also

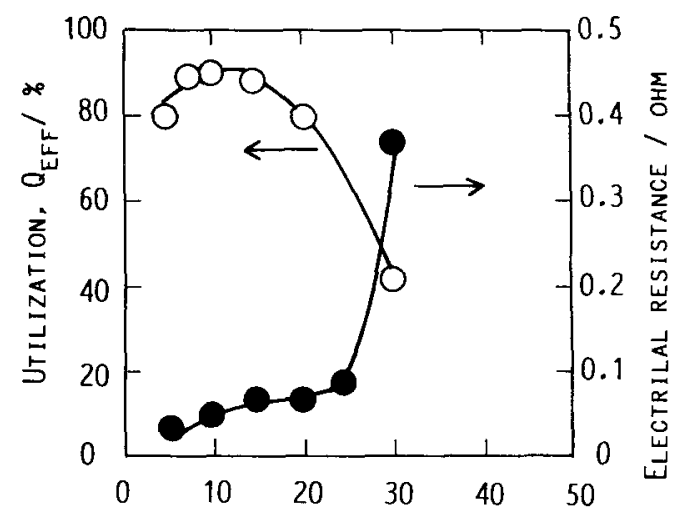

VOLUME FRACTION OF SB RUBBER/ $\%$

Fig. 11 Utilization ( $O$ ) and electrical resistance (O) of copper Chevrel electrode sheets with different volume fractions of SB rubber: utilization was obtained by discharging test cells on $0.5 \mathrm{~mA}$ at $20^{\circ} \mathrm{C}$ down to 0.30 volt after they were charged at 0.60 volt overnight.

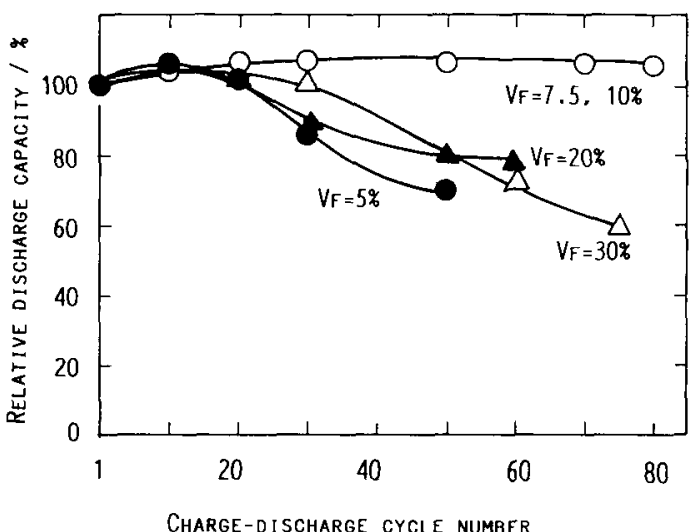

Fig. 12 Charge - discharge cycle performance of test cells having copper Chevrel electrode sheets with different volume fraction of SB rubber: test cells were charged at 0.60 volt and discharged on $0.5 \mathrm{~mA}$ repeatedly at $20^{\circ} \mathrm{C}$. 
measured by pressing it between $\mathrm{Pt}$ discs $10 \mathrm{~mm}$ dia. at $20^{\circ} \mathrm{C}$ (Fig. 11). Remarkable changes both in utilization and electrical resistance were obtained between 20 and 30 vol.\%. These change might be attributed to the breaking of electronic conduction network in the electrode sheet.

Figure 12 shows the result of chargedischarge cycle test for the cells having Chevrel electrode sheets with $5,7.5,10,20$, and 30 vol.\% SB rubber. They were charged at a constant voltage of 0.6 volt and discharged at a constant current of $0.5 \mathrm{~mA}$ repeatedly in the range of 0.6 to 0.3 volt at $20^{\circ} \mathrm{C}$. Charging was switched to discharging after five minute interval when the charging current decreased below $10 \mu \mathrm{A}$, because almost $100 \%$ of capacity were found to be charged until the charging current decreased below $10 \mu \mathrm{A}$. The cells with 7.5 and 10 vol.\% provided $100 \%$ of their initial capacity after 80 cycles, however the cells with less SB rubber of 5 vol.\% or much of 20 and 30 vol.\% provided poor cycle life. Electrode or electrolyte particles might be easily loosed in the 5 vol.\% sheet by repeated charging and discharging because less SB rubber binder hardly tie up the particles together. In the 20 or 30 vol.\% sheet, a slight displacement of the electrode or electrolyte particles caused by repeated charging and discharging might break its fragile electronic network.

The SB rubber content of the Chevrel electrode sheet was optimized to be 10 vol.\% by considering both utilization and chargedischarge cycle performance.

\subsection{Charge-discharge performance}

The test cell with optimized solid electrolyte and electrode sheets was charged at a constant voltage of 0.6 volt and discharged at a constant current of $0.5 \mathrm{~mA}$ repeatedly in the range of 0.6 to 0.3 volt at $20^{\circ} \mathrm{C}$. The discharge capacity relative to the first cycle capacity was plotted against charge-discharge cycle number in Fig. 13. The cell was capable of providing over $90 \%$ of its initial capacity even after 1000 time charge-discharge cycles. Constant current charge-discharge cycle test was also carried out for a piled battery of 3 unit cells $15 \times 15 \mathrm{~mm}$ in

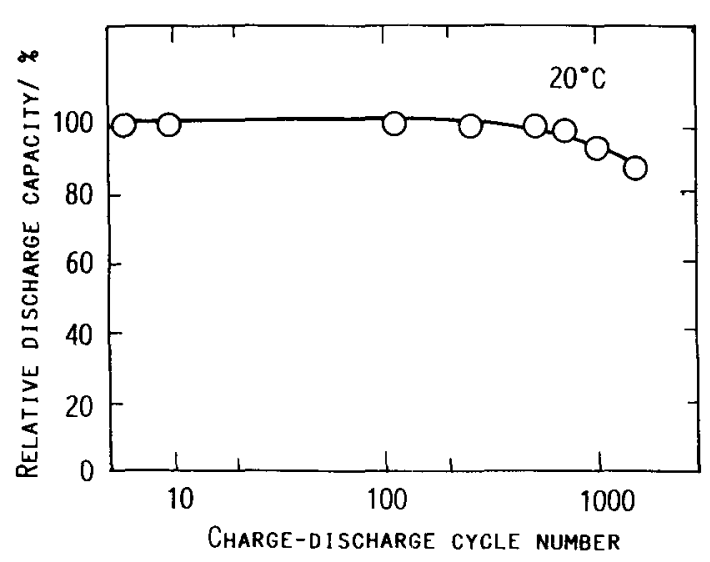

Fig. 13 Charge-discharge cycle performance of test cells having a solid electrolyte sheet with optimized SB rubber content of 65 vol. \% and copper Chevrel electrode sheets with optimized SB rubber content of 10 vol.\%: test cells were charged at 0.60 volt and discharged on $0.5 \mathrm{~mA}$ repeatedly at $20^{\circ} \mathrm{C}$.

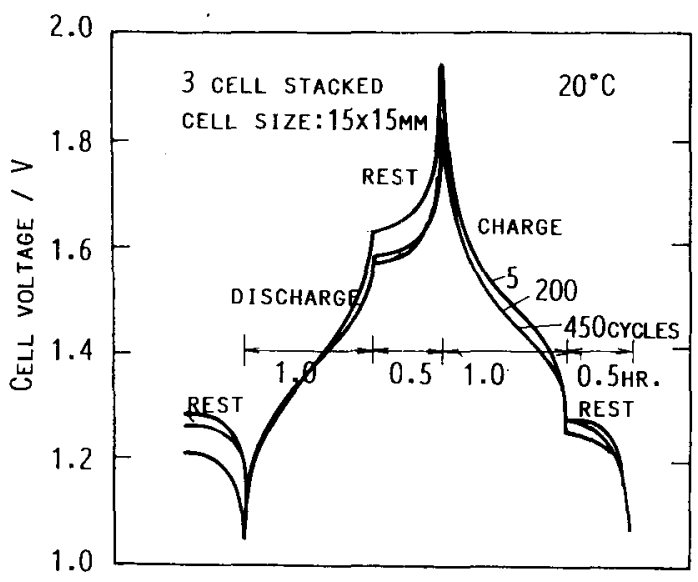

Fig. 14 Charge-discharge curves of a stacked cell consisting of three unit cells $15 \times 15 \mathrm{~mm}$ in size: the cell was charged and discharged on a constant current of $0.75 \mathrm{~mA}$ each for $1 \mathrm{~h}$ with $0.5 \mathrm{~h}$ interval.

size. It was charged and discharged each for $1 \mathrm{~h}$ with $0.5 \mathrm{~h}$ interval on $0.75 \mathrm{~mA}$ at $20^{\circ} \mathrm{C}$. No degradation was observed in the charging and discharging curves within the tested number of cycles, 450 times (Fig. 14).

\section{CONCLUSION}

Besides an advantage of flexibility, mixing of SB rubber with solid electrolyte particles brought an unexpected effect of reducing the leak current of the solid state cell without increasing its internal resistance. The ionic conduction in the 
solid electrolyte sheet was not greatly lowered as long as the SB rubber content was limited to below 70 vol. \%. In the range of 20 to 70 vol.\% there might be a critical value above which copper ion conduction through the SB rubber layer coated around the solid electrolyte particles was permitted, but electronic conduction was prohibited. As for the Chevrel electrode sheet, the electrical resistance was increased remarkably around $30 \mathrm{vol} . \%$ and the utilization of the electrode was also decreased largely around 30 vol.\%.

The solid electrolyte cell employing solid electrolyte sheet with optimized SB rubber content of 65 vol.\% and copper Chevrel phase compound electrode sheet with optimized 10 vol.\% was found to provide a longer shelf life, a higher current output, and an excellent chargeddischarge cycle life.
The authors would like to thank Japan Synthetic Rubber Company for preparing the electrolyte and electrode sheets.

\section{REFERENCES}

1) B. C. H. Steele, Proceedings of NATO Advanced Study Inst., 163 (1985).

2) P. V. Wright, Polymer, 7, 319(1975).

3) M. B. Armond and M. Duclot, USP4,303,748 (1978).

4) P. Ricoux, J.-M. Chabagno, D. Muller and P. Rigaud; M. B. Armand and D. Deroo, J. Electrochem Soc., 132, 1333 (1985).

5) R. Kanno, Y. Takeda, M. Ohya and $O$. Yamamoto, Mat. Res. Bull., 22, 1283 (1987).

6) T. Takahashi, O. Yamamoto, S. Yamada and S. Hayashi, J.Electrochem. Soc., 126, 1654 (1979).

7) S. Yamamoto, K. Matsui, M. Wakihara and M. Taniguchi, Mat. Res. Bull., 18, 1311 (1983).

8) S. Kondo, T. Sotomura, and T. Kambara, US Patent No. 4789610, filed Sep. 11, (1987). 